\title{
Unleveled Playfield and Democracy in Tanzania
}

\author{
Alexander Boniface Makulilo ${ }^{1}$ \\ ${ }^{1}$ University of Dar es Salaam, Tanzania \\ Correspondence: Alexander Boniface Makulilo, Department of Political Science \& Public Administration, \\ University of Dar es Salaam, P. O. Box 35042, Dar es Salaam, Tanzania. E-mail: makulilo76@yahoo.co.uk
}

Received: November 7, 2011 Accepted: January 6, 2012 Online Published: May 11, 2012

doi:10.5539/jpl.v5n2p96

URL: http://dx.doi.org/10.5539/jpl.v5n2p96

\begin{abstract}
Tanzania experienced a top down democratic transition. This transition path gave the ruling party monopoly to determine the transition pace, design the rules of the game, as well as to own and benefit out of it. The de-linking of the party from the state of the previous authoritarian regime has yet happened thereby creating uneven playfield for opposition parties to be effective. This article, based on documents, interviews, and newspapers, holds that the landslide victories by the ruling party in the past general elections of 1995, 2000, 2005, and 2010 were largely attributed to its fusion with the state.
\end{abstract}

Keywords: Tanzania, elections, democracy, constitution, CCM, state-party

\section{Introduction}

Tanzania got its independence on 9 December 1961 from British colonialism based on a multiparty system. However, in 1965, this system was changed to a single party system. The Tanganyika African National Union (TANU), then the ruling party, spearheaded the introduction of one party state with the effect of suffocating the political space. Unity was considered by TANU as the rationale for the new political system. During that time, all political activities in Tanzania, apart from those of the organs of the state were conducted by or under the auspices of the party. In 1975 the party became supreme. Article 3(3) of the constitution of the United Republic 1977 provided that all political activities in the country and those of the organs of the state should be conducted by or under the auspices of the party. It was in 1992, following the pressure from within and without Tanzania, that the country adopted multiparty democracy. Though the specific articles referring to the single party system were repealed, the practice has almost remained unchanged.

Since 1992, Tanzania has conducted four general elections in 1995, 2000, 2005, and 2010. The ruling party, Chama Cha Mapinduzi (CCM) won landslide victory in all the previous elections. The minimum popular support for CCM has stood at $60 \%$, but in 2000 it went up to $71 \%$. It was in 2005 that the party obtained a historical record of popular support of about 80\% (NEC 1996, 2001, 2006, and 2011). Against that backdrop, this article revisits the law and practice in Tanzania with regard to multiparty democracy. Its core argument is that the ruling party is fused with the state hence militating against the survival and effective operations of opposition parties. The article focuses to understand three key areas namely the rules of the game, media, and security forces.

\section{State-Party: A Conceptual Overview}

Transition from one party system to multiparty democracy requires first and foremost de-linking of ruling parties from states. This is due to the fact that when a one-party dominant regime is a direct descendant of a party-state system, the properties of this new regime often-times constitute a half-way house between authoritarianism and democracy consequently leading to uneven playing field which militates against the survival of opposition parties (Chu 1999:62). The playing field is considered uneven to the extent that incumbent abuse of the state generates such disparities in access to laws, resources, media, or state institutions that opposition parties' ability to organize and compete for national office is seriously impaired (Levitsky and Way 2010:64). Arguably, the project of consolidating the party-state also needs a takeover of the public sector. While this kind of regime conducts regular multiparty elections at all levels of government, violation of basic democratic standards are done in serious and systematic ways (Schedler 2010:69). And therefore one major problem of the transition is to untangle, both practically and in people's minds, the links which were so carefully forged between the party and the state property, functions and personnel (Huntington 1991:209). The de-linking process usually takes place following the introduction of impartial laws, strong oversight institutions, elite fragmentation, or due to military 
takeover. In relation to the latter strategy, several works from the literature on political oppositions suggest that disloyal and unconventional strategies are more likely to occur in regimes that do not allow significant inter-party competition (Franklin 2002:522). In Zambia, for example, in 1991, the United National Independent Party lost power to the opposition party, the Movement for Multiparty Democracy mainly because of the personalisation of the party by Mr. Kenneth Kaunda and elite fragmentation. This was also the case with the Kenya African National Union which fragmented in 2002 as a result of elite factionalism based on ethnicity.

The phenomenon of uneven playing field is pervasive in the hitherto single party systems that some scholars describe it as "state-party" (Shivji 1991; Widner 1992; Makulilo 2008). In this case, state-party refers to a political party that survives and operates solely by relying on coercive instruments and resources of a state. That party suffocates political space for other actors to play their roles effectively. State-party can either be a de jure or de facto category, and in some cases in both forms. In de jure, a party is made state-party by law and hence derives its authority from there as opposed to a party which derives its legitimacy from, and a part of, the civil society. Such party, increasingly and frequently, begins to depend on the use of coercion, which is a characteristic per excellence of the state, rather than persuasion, which is a characteristic of an organization of the civil society (Shivji 1991:2). In contrast, a state-party is regarded as de facto when the marriage between the party and the state is visible in practice (Makulilo 2008: 29-30). It should be emphasized that although state-party transcends election, its features become more evident during elections where power struggle takes place.

The most typical cases of state-parties include the former Soviet Union. Sometime after the October revolution and the Civil War (1918-1920), the Communist Party of the Soviet Union ceased to be a political party per se. Nowadays it has been often called a state party (Komarov 1992:58-9). In many African countries, state-party came as early as in 1960s. The heyday of state-party culminated into the centralised states. This made the theory of the precedence of the party over the state to be an official doctrine (Wallerstein 1966:206). To be sure, the ZANU-PF party in Zimbabwe exhibits the state-party (Bratton and Masunungure 2008:44-5).

Yet, after four decades, the access to state resources by political parties in Africa remains the exclusive rights of those parties that win elections (Biezen and Kopecky 2007: 251). For one thing, with state power, these parties have state-command over resources with which they can sustain and expand their political organisations. Indeed, they have hyper-incumbency advantages and therefore enjoy huge material resources at the expense of the opposition parties. As a general principle, resource endowments deeply affect political parties and their ability to compete. Resource-rich parties attract better candidates, have ability to campaign widely, and they are able to buy large amounts of air time in the mass media (Greene 2007:39). It is universally argued that money is recognised to shape the contours of electoral competition and democratic representation. As such, most campaigns do not revolve around policy commitments; instead, campaigns remain as contests in which candidates spend time, energy, and money to win (Samuels 2001:569; Meirowitz 2008:681). This is achieved when those parties in power control the governments fully. Furthermore, rulers employ coercive instruments of state especially when unable to win popular support using more legitimate methods (Katz and Mair 1995; 2002). The next section discusses state-party fusion in the context of Tanzania. It examines how such fusion militates against the multiparty democracy. As stated at the beginning, the article focuses to understand the rules of the game, media, and security forces as embodiment of state-party.

\section{Rules of the Game}

The main rules of the game in Tanzania constitute the Constitution of 1977, the Elections Act. No. 1 of 1985, the Political Parties Act No. 5 of 1992 and the Election Expenses Act. No. 6 of 2010. However, the constitution is the fundamental norm of the land. Historically, the constitution has evolved through four phases: The independent constitution of 1961, the Republican constitution of 1962, the interim constitution of 1965 and the permanent constitution of 1977 (the current constitution in use). There are six distinctive features about these constitutions: Firstly, they all did not involve public debate and discussion in their making; secondly, with the exception of the independence constitution, the rest tend to concentrate and centralize power to the executive arm of the government and particularly the chief executive .i.e. the president (head of state, head of government, head of public service, commander-in-chief of all armed forces); thirdly, they raise the ruling party to the pinnacle of power by making it the supreme organ in the United Republic; fourthly, they suffocate association life of autonomous organizations such as trade unions, cooperative unions and other civil societies; fifthly, they did not incorporate the Bill of Rights (note that the Bill of Rights firstly appeared in the constitution of the United Republic in 1984); and sixthly, the ruling party is the sole maker or un-maker of the constitution through amendments. The sum total effect of all these constitutional tendencies is the politics of hegemony by the ruling party and the resultant repressive political culture over the last four decades since independence. 
There are two critical areas about the constitution and state-party fusion. The first area is on the fundamental principles and national ethics. In a pluralist system of government, the fundamental and national principles in the constitution should be of such a nature that any political party elected to form a government respects them. For that reason, ideologies and related ideological policies should not be included in the state constitution rather they should appear in the relevant parties' constitutions, election campaign programmes and manifestos (URT 1991:143). In Tanzania, these principles are enshrined in Part II of the constitution of the United Republic (URT) with the title "Fundamental Objectives and Directive Principles of State Policy". A critical examination of this part reveals two facts: One is that such principles are tailored around the mono-party political system, and two is that the principles reflect CCM's ideology and policies. Ideologically, the constitution is founded on Ujamaa a form of socialism [Article 3(1) and Article 9 of the constitution of the URT 1977]. Interestingly, Ujamaa is the very same CCM's ideology [Article 4(3) and Article 5(3) of CCM's Constitution 1977]. In this sense, the party is not only a special ideological apparatus of the state but it also uses repressive apparatus to consolidate its hegemonic position. On the eve of transition to a multiparty system, the Nyalali Commission posited that Articles 8 and 9 of the constitution of the United Republic of Tanzania and likewise Sections 9 and 10 of the Zanzibar Constitution qualify to form the fundamental principles and national ethics. Strikingly, these Articles are inextricably connected to the mono-party political system. They set strategies that have ideological orientation of Chama Cha Mapinduzi (URT 1991: 143). The former President Benjamin Mkapa once said that the most important indicator of the life of the party is the continuity of the Union between the Republic of Tanganyika and the Peoples' Republic of Zanzibar. TANU and ASP which later on united to form Chama Cha Mapinduzi made the United Republic possible. Under such circumstance, therefore, the continuity of the Union is a thermometer to the life of CCM (CCM 2006).

In concrete terms, Article 8 of the state constitution provides for the policy of the two government structure for the Union between Tanganyika and Zanzibar. This is also a CCM policy towards the Union. These Articles were among the factors that prompted the commission to recommend for a completely new constitution as it stated "Under political pluralism the Constitutions should be written afresh" (URT 1991:142). The CCM government did not accept this recommendation. It simply repealed constitutional articles that stated directly to the effect of the one party system and party supremacy.

Yet, in 1999 a special presidential committee on constitutional reforms conducted a study and one of its findings was that $88.8 \%$ of Tanzanians identified themselves with Ujamaa and therefore wanted it to remain in the constitution as a national vision. However, the committee recommended that Ujamaa being the ideology of one party, under the current multiparty system, favours CCM at the expense of other parties and it should be removed (URT 1999). Despite the fact that Ujamaa is no longer a practical ideology, it remains a significant mobilizing tool for the ruling party during elections. This observation is consistent with the findings by the Afro- Barometer survey and conclusions of 2002 that Tanzanians are "uncritical citizens" partly oriented towards the socialist ideology and one-party structures inherited from the old regime. The ordinary people has not yet developed the healthy scepticism about authority, the independence of preferences, and the courage to take action that are the life blood of functioning democratic and market systems (Chaligha 2002). It is important to note that the major actors in the multiparty politics dispute the constitution and want a new one in line with the recommendations made by the Nyalali commission in 1991. For example, opposition parties dispute the constitution and would want a new one (Note 1). However, in 2007 the Research and Education for Democracy in Tanzania (REDET) conducted a survey on the performance of political parties in Tanzania. One of the questions was whether a new constitution would help opposition parties to gain in terms of electoral performance. It was observed that $52.0 \%$ of respondents opined that it would not help; $20.2 \%$ responded that it would; $21 \%$ said that they did not know; and $6.1 \%$ opined that it would depend on the availability of subsidies, level playing field, good policies and cooperation among themselves. Surprisingly, the same survey observed that about $30 \%$ of all respondents could not even mention by name a national chairperson of their respective parties. How could they be able to comprehend a technical question on constitution and fail to respond to a practical one about the party chairperson? From the face of the survey, it would seem that the constitution is not a problem in the current multiparty system. But the framing of REDET's question was problematic due to the fact that most of Tanzanians are "uncritical citizens"; and so the logic of the question would be whether in the first place they knew such a thing like constitution before probing its impact on opposition political parties. The fact is that most Tanzanians have never seen the constitution leave alone reading it (Satu 2007; Ruotsalainen 2009). This problem is even bigger in the rural villages where about 80\% of Tanzanians live as Ngware once noted "It is no secret that the average Tanzanian suffers from a total ignorance of basic legal rights” (Ngware 1997:246). This ignorance always works in favour of CCM. This is true as majority of Tanzanians in the rural areas, the only political party they know is CCM. They also know the founders (of CCM) and would like to allow them continue in office (Mallya 2006:414). 
The second area is on the powers of the president. In Tanzania, the evolution of constitution since independence indicates that the president is a very powerful figure indeed with almost absolute power under the constitution. Most of such power is discretionary. It should be pointed out that there are no effective safeguards to control the exercise of that power. The best and the only remedy against the possible abuse of power in fact remains with the president himself or herself. The overall picture which emerges here is that constitutional grounds are so fertile such that the seeds of dictatorship benevolent or otherwise may be sown, sprout and flourish (Ong'wamuhana 1978). This is true as the then President of the United Republic of Tanzania, Mwalimu Julius K. Nyerere once remarked "I have sufficient powers under the constitution to be a dictator" (Quoted in Shivji 1993). Similar statement was made by President Jakaya Kikwete on 21 August 2008 when addressing the members of Parliament. He said that the President has immense powers and that without being careful, he or she will abuse it (Kikwete 2008). In Tanzania, the president is the head of state, head of government, commander-in-chief of armed forces, and above all he or she is always in practice the chairperson of the ruling party [Note that under the party constitution the chairperson need not necessarily be the head of state as per Article 105(1) of the Constitution of CCM 1977]. It is contended that if the president who is the all powerful head of state is also the chairperson of the party it becomes presumptuous to imagine that the party can control the executive including its head who is the serving chairperson of the party (Ong'wamuhana 1978: 260). Besides, the government in power is constitutionally the government of the party implying that senior party factionaries are mostly the senior government personnel.

Moreover, the president appoints the Regional and District Commissioners as per Article 61 of the Constitution of the URT 1977. These government officials are required to supervise the discharge of all the duties and functions of the government in the respective regions as specified by law. Worse still, the president appoints the Directors and other executive officers for the Local Government Authorities as per Local Government (District Authorities) Act. No. 7 of 1982 and Local Government (Urban Authorities) Act. No. 8 of 1982. It is important to note that according to the CCM's Constitution 1977, all government officials in the regions, districts, divisions and wards are supposed to serve the interests of the ruling party. It is not uncommon therefore to find such officers sit in CCM's meetings in their respective areas (URT 1999). Indeed, one of the most significant resources that CCM has always won is this government structure at the grassroots level. The Tanzania Election Monitoring Committee (TEMCO 1997: 192-5) provides concrete cases on how CCM benefited from the government administrative structure and resources during the 1995 elections. Starting from the village level to the region, the impact of the executive officers, district and regional commissioners was exact. The village executive officers (VEO) and ward executive officers (WEO) would naturally tend to support CCM because the councils which appointed them are solely controlled by CCM and their boss, the district executive director (DED) is appointed by the president. The fact that CCM government controls the local government system means that the party has a guaranteed support of the government structure. The then Kigoma Regional Commissioner (RC), Mr. Yusuf Makamba, a staunch and die-hard CCM cadre who does not make any secret of it was reported to have held several meetings with divisional secretaries, ward executive officers and heads of government departments in Kigoma and Kasulu towns urging them to mobilize the people to register and vote for a party "which would guarantee them retention of their posts." As he put it clearly that "if the water dries, the fish is bound to die" meaning that if the ruling party lost, they would lose their job. It should be recalled that the returning officers used the VEOs and WEOs for many election activities ranging from the distribution of election materials to adding up election results contrary to the Elections Act. No. 1 of 1985.

In the 2000 elections, the situation did not change. According to TEMCO the Mtwara District Commissioner (DC) stopped commercial activities at Nanyamba market so that people could attend CCM's meeting for their presidential candidate, Mr. Benjamin Mkapa. The commissioner threatened to fine and revoke business licenses to ensure compliance. Moreover, he sent a letter to a sheikh, a priest and a headmaster asking them to encourage people to attend a CCM rally (TEMCO 2001:87). Similarly, in the 2005 elections, the status quo was sustained. TEMCO reported that the Regional Commissioners, District Commissioners, Division Officers, and Ward Executive Officers who are supposed to serve all political parties impartially supported CCM with typical examples from Shinyanga and Rukwa regions (TEMCO 2006:75-6). Indeed, the government structure at the grassroots level remains a life blood of CCM in terms of mobilizing supporters and resources. And therefore, the claim that CCM has a strong structure from the grassroots to the national level need not be unquestioned. TEMCO (2006) posits that there can never be fair elections in Tanzania until these officers are defused from the CCM structure.

Similarly, the president appoints the Registrar of political parties as per the Political Parties Act. No. 5 of 1992 and can remove the same at his or her own discretion. Section 4(1) of the Act states "There shall be a Registrar 
of Political Parties in the office of the Prime Minister or in such other office as the President may determine who shall be appointed by the President.” No wonder, the office of the Registrar can be viewed as a department subject to directives of the prime minister or a minister responsible for legal affairs. On the eve of the 2005 general elections, the then Minister for Home Affairs and CCM Publicity Secretary, Mr. Omar Ramadhani Mapuri was quoted saying that CCM was just doing a warm-up before the match started, the Registrar should leave them alone and concentrate on his clerical job (Mbaruku 2005). Mr. Mapuri was here reacting to the order from the Registrar with the effect that CCM stops electoral campaigns for its nominated presidential candidate (Mr. Jakaya Mrisho Kikwete) ahead of official campaign. That act contravened the Political Parties Act. No. 5 of 1992 and the Elections Act. No. 1 of 1985. Mr. Mapuri's statement expresses the behaviour of CCM over the office of the Registrar since as I have already pointed out, the president of the United Republic, who at the same time is the chairperson of CCM, holds the appointment and dismissal powers of the Registrar. This evidences that the Registrar is constrained in executing his or her duties by the immense powers of the president. And therefore to reduce the mandate and powers of the registrar to that of a mere clerk is to admit the powers of CCM over that office.

Another institution that is directly under the influence of the president and chairman of the ruling party is the National Electoral Commission (NEC). Article 74 of the Constitution of the URT 1977 empowers him or her to unilaterally nominate commissioners of the NEC. These commissioners have no guaranteed tenure of office. Yet NEC does not have its own independent budget deliberated by the parliament. All these factors undermine the independence of this crucial institution. There is no way, NEC as one of state apparatuses can avoid implementing the president's wishes either openly or secretly. It can generally be learnt therefore that the constitutional clauses which purport to declare NEC as an independent department do not offer and protect such independence in a practical sense. In its reports for the general elections of 1995 and of 2000 TEMCO states very categorically that while the Constitution of the URT 1977 Articles 74(7)(11) (12) and the Elections Act section 4(2) ideally purport to accord an independent status to NEC, practically, however, the NEC does not pass the basic tests of an independent institution. These include the appointment procedures of the commissioners, lack of independent finance, lack of security of tenure of office by commissioners, and the utilization of senior government personnel at the regional, district and constituency levels. Under such circumstances, all stakeholders, except CCM, view NEC as partial (Makulilo 2009).

\section{Security Forces}

Although on the eve of multiparty system, the Nyalali Commission (URT 1991: 177-8) recommended for the separation of the party from security forces to ensure the forces are apolitical, it is evident that the security forces have remained politicized in the current multiparty system to favour the ruling party. This is in sharp contrast with Article 147(3) of the URT constitution 1977 which provides that "It is hereby prohibited for any member of the defence and security forces to join any political party save only that he shall have the right to vote."

The presidency is the highest institution that forges the relationship between the ruling party and security forces. As the commander-in-chief, the president appoints all the top commanding officers of the armed forces, recruit people into and their removal from the armed forces, appoints commanders of various units of the armed forces and supervise any power vested in any member of the armed forces. The president may command the armed forces to engage in any operations within and outside Tanzania. The order of the commander-in-chief is constitutional and binding to all the armed forces and therefore it should be respected [Article 148 (1), (2) and (3) of the URT Constitution, 1977]. Being CCM's chairperson and the president (with wide discretion), the commander-in-chief, may misuse such powers in favour of his or her party. During the 2000 elections, for example, the former president of the United Republic, Mr. Benjamin William Mkapa (then an incumbent president and a presidential candidate in that election) used a police helicopter to campaign in the remote regions. The same practice was done by the retired president, Mr. Ali Hassan Mwinyi to campaign for CCM in the Coast region and Kigoma (TEMCO 2001: 86-7). It is evident that the conflict of interests between the president and the party is paramount. Elsewhere, as I noted, president Mkapa pledged to deploy state apparatuses to ensure CCM win the 2005 elections with a 'tsunami effect' (ushindi wa Tsunami) and it was so (Makulilo 2008). There is no doubt that this statement influenced the behaviour and conduct of the armed forces in that election. In his official address to the Members of Parliament on 21st August 2008, the President of the United of Republic of Tanzania, Mr. Jakaya Mrisho Kikwete said regarding his imperial powers as a president over the Inspector General of Police (IGP). He said that if the president orders the IGP, Said Mwema to arrest any person, it would be so. Arrest Dr. Slaa (Note 2), he would be arrested. The IGP would implement president's orders without any question. Arguably, the above incidences reveal the fusion between the presidency and CCM. It is not surprising that, in his inaugural speech to mark the opening of the parliament after his victory, Mr. Kikwete was quick to 
express his thanks to the security forces as he once put: "I want to commend our defence and security, and law and order organs, for a job very well done in insuring that Tanzania remains peaceful during the entire electoral process. The top leaders, commanders, officers, men and women from these organs were loyal to the Nation, and showed great patriotism. I congratulate them" (Kikwete 2005). The use of security forces repeated during the 2010 general elections. CCM started campaigning that opposition should not be elected since they would shed blood. The climax of this campaign was for the security forces to intervene the matter. The Tanzania People's Defence Forces, Chief of Staff, Lt. Gen. Abdurrahman Shimbo, the Deputy Director of Criminal Investigations, Mr. Peter Kivuyo and the Head of the Police Special Operations Unit, Mr. Venance Tossi called a press conference to threaten people on security. They said that no blood would be shed by any political party since they were full prepared to handle the situation. Gen. Shimbo said "There have been signs of disrupting peace and tranquility in the ongoing campaigns...some politicians have even dared threatening to shed blood. Let them be warned that we are firmly prepared to make sure that no single drop of blood will be shed during the ongoing campaigns, the Election Day and after that" (Daily News 01.10.2010). Although there were many parties contesting, this statement aimed at frustrating CHADEMA which seemed to offer stiff competition to CCM. In response to the threat, on 4 October 2010 CHADEMA wrote a letter with reference No. C/HQ/ADM/SG/02/79 to the Dean of Diplomatic Corps, international organizations and all parties to condemn this tactics (The Citizen 07.10.2010). The head of the European Union Election Observation Mission (EUEOM) to Tanzania, Mr. David Martin described the security threat as disappointment and frustration to democracy (The Citizen 07.10.2010). After the public outcry from politicians, activists and non-governmental organizations (NGOs) that the security forces were used to further the interests of CCM, proper authorities particularly the National Electoral Commission (NEC) maintained that there was no any threat with regard to peace (The Guardian 07.10.2010).

\section{Media}

Media in this context is treated concomitant with information. The access to information is essential to the health of democracy. This is because it ensures that citizens make responsible and informed choices rather than acting out of ignorance or misinformation. Moreover, information serves a "checking function" by ensuring that elected representatives uphold their oaths of office and carry out the wishes of those who elected them (Centre for Democracy 1999). In a democratic polity, this role is carried out by media. It is argued that media is an important element for free and fair elections since it facilitates freedom of expression (Hameso 2002:6). Indeed, contemporary election campaigns are increasingly dominated by national television, radio and press coverage (Forrest and Marks 1999:99).

In Tanzania, freedom of expression is enshrined in Article 18 of the Constitution of the United Republic and it states that (a) every person has the right to freedom of opinion and expression, (b) seek, receive and impart or disseminate information and ideas through any media regardless of national frontiers, (c) the right of freedom from interference with his communications, and (d) the right to be informed at all times of various events in the country and in the world at large which are of importance to the lives and activities of the people and also of issues of importance to society. Further to the above clause, freedom of expression is regulated by the following legislations: The Newspaper Act. No. 3 of 1976; the Tanzania Communications Regulatory Authority Act. No. 12 of 2003; the Broadcasting Services Act. No. 6 of 1993; the Zanzibar Broadcasting of News Agents, Newspapers and Books Act. No. 5 of 1988; Public Corporations Act, 1992; the Records and Archives Management Act. No. 3 of 2002; the National Security Act. No. 3 of 1970; the Tanzania Intelligence and Security Service Act. No. 15 of 1996 and the Penal Code. These laws are in principal the enemy of the mass media.

Until 1992, the media in Tanzania were the organ and agent of the sole ruling party, CCM. The available media of the time (Radio Tanzania, Dar es Salaam Radio Tanzania, Zanzibar, Zanzibar Television, Daily News and the Sunday News) served the interests of the state-party (Luanda 1997:118). Media became instruments of propaganda. At the eve of multiparty system, the country saw the proliferation of "independent" press. There are dozen weeklies, fortnightlies, or monthlies in Kiswahili or English with a reasonable circulation. However, the electronic media remain under monopoly control (Shivji 2006:253). This is not surprising as the Electoral Institute of Southern Africa (EISA 2003:18) maintains that the freedom of the press as a fundamental right is guaranteed in most Southern Africa Development Community constitutions. Yet, in many countries the ruling party dominates the public media.

Public media being run by tax-payers' money are obliged to be impartial in conducting their businesses during elections. Section 53(1) of the Elections Act. No. 1 of 1985 provides candidates for the office of the president and vice-president of the United Republic and political parties participating in an election with the right to use the state radio and television broadcasting service during the official period of election campaign. Subsection 3 
furthers that "[e]very print media owned by the government which publishes any information relating to the electoral process shall be guided by the principle of total impartiality and shall refrain from any discrimination in relation to any candidate journalistically and in the amount of space dedicated to them." For the purpose of giving binding effect to this law, Section 53(4) of the Act gives the National Election Commission mandate to issue directives to any government owned media.

Seen from its face value, the intention of this law is to ensure fairness among contestants during elections. However, evidence abound to show that since the introduction of the multiparty system, CCM has enjoyed a favourable air-time and space coverage in the public media like the National Television (TVT), Television Zanzibar (TVZ), Radio Tanzania Dar es Salaam (RTD), Radio Zanzibar (STZ), the Daily News, Sunday News and Zanzibar Leo. In the case of Attorney-General v. Aman Walid Kabourou [1996] T.L.R 156. following the Kigoma by-election, the Court of Appeal of Tanzania held that "CCM was given more air-time on Radio Tanzania Dar es Salaam than were given other political parties, and its broadcasts generally were biased in favour of the CCM candidate, such that it must have influenced the by-election results in favour of the CCM candidate”. This tendency repeated in the first general elections of 1995. It was noted that CCM enjoyed a lion's share of air time and space coverage in the public media. The Association of Journalists and Media Workers (AJM) observed that from 4 to 21 September 1995, the third week of electoral campaigns, CCM and its presidential candidate enjoyed absolute monopoly of campaign broadcast coverage over the RTD news bulletin by $63 \%$ and Majira programmes by 52\% (AJM 1995:1). It is along this premise that TEMCO argues that despite the efforts put by the court and National Election Commission the media continued to work in favour of the ruling party (TEMCO 1997:181).

The situation did not change in the 2000 elections. In its report on media and election, the Media Council of Tanzania (MCT) reports that the media was biased in favour of CCM. For example, in October, the RTD gave CCM and its candidates $91 \%$ of coverage while the STZ gave CCM 67\%. On televisions, in September, TVT gave CCM 96\%; and between 17 and 30 September, it gave CCM's presidential candidate Mr. Benjamin William Mkapa 100\% (MCT 2000:66). This situation became the worst in the 2005 elections. The Media Institute of Southern Africa (MISA 2005: 3-4) shows that RTD and STZ allotted 105,971 seconds to CCM while the next largest party was CUF which got 31,557. Similarly the TVT and TVZ allotted CCM 114,475 seconds, followed by CHADEMA 22,287 seconds. It should be noted that state radios and televisions broadcast countrywide. CCM dominates the media in terms of news items and editorial reports. Yet, the private media which is supposed to act independently and impartially have also fallen victims of the state-party. Through laws, manipulation or force they are restricted and in some instances suspended or completely banned. The CCM government has not learned to operate in an environment of criticisms and to accept truth. For example, until 1995, the Cheka, Mwanamama, Rafiki, and Michapo papers were already banned. Threats to ban more papers are still around. The weekly Mwanahalisi paper which is very critical to the CCM government was suspended its operation for three months starting from October 2008. Two reasons can be advanced to explain why the media is biased to favour CCM. One is the fear of reprisal. The public employees in the media sector are people who are supposed to be loyal to the government of the day. They must make sure that they favour its interests (URT 2005). In connection to that, one MP from CCM, Hon. Beatrice Shellukindo remarked "Hon. Speaker, I have worked in the government for 21 years, it is very true that if you are not coward you will be sanctioned. Since I completed my Second Degree, I had only been in the same job position for 14 years without any promotion, why? I speak truth and I do not want to be coward. Finally it reaches a point that you must quit" (Own translation Note 3). This statement from an experienced civil servant reveals the secrecy of the public service and the behaviour of its workers. From such practices, it could be argued that while the law is clear on the behaviour of government employees towards parties, the practice has been a contrast as most of employees either because of pressure from the party out of their own will and partisanship feel the obligation to work in favour of the ruling party in order to secure their tenure in office or promotion. Second is about the laws themselves which undermine the independence of media. Similarly, in the 2010 elections CCM continued to enjoy a lion's share of coverage in both state and private media. Throughout the election, CCM prevailing dominance in coverage was evident from all media. For example, in September 2010, the distribution of coverage from both state and private media was as follows:- For the print media, CCM received $163,900 \mathrm{cms}$ which is about $48 \%$, CHADEMA received $81,914 \mathrm{cms}$ equivalent to approximately $24 \%$, CUF got $40,874 \mathrm{cms}$ or $12 \%$ and NCCR - Mageuzi received a total of $13,667 \mathrm{cms}$ of coverage or $4 \%$ while TLP received $11,021 \mathrm{cms}$ or $3 \%$. On electronic media specifically the radio, CCM received 133,630 seconds equivalent to $43 \%$, followed by CUF which had 81,720 seconds equals to $26 \%$ and CHADEMA had 67,885 seconds equivalent to $12 \%$. On television, CCM obtained 161,753 seconds or $40 \%$, then CHADEMA with 83,188 seconds or $20 \%$ of the airtime and CUF with 50,375 seconds or $12 \%$ (Synovate 2010). 


\section{Conclusion}

This article has shown various strategies that are used by the ruling party and its government to constrain democracy. The strategies are de jure and de facto in nature. The presidency is the most important asset for the ruling party. Being attached with discretional powers, CCM strategically exploits this opportunity by fusing itself to the institution of presidency. The president is at the same time the chairperson of the ruling party. Both, the state and CCM's constitutions provide immense powers to the "president-chairman". With such powers, he or she is able to appoint the entire electoral machinery. The president appoints the National Election Commission, the Registrar of Political Parties, the Inspector General of Police, and the bureaucrats. He or she does appoint all these officials unilaterally and dismisses them when it pleases him or her. Moreover, CCM controls the local government system which makes it possible to spread countrywide. Being involved in conducting elections, this system works in favour of the ruling party. The laws of the land cement this relationship between the party and the local government system. The fusion still binds together the interests of all elites. With the absence of strong social cleavages and oversight institutions, the ruling party has managed to remain strong for decades. Indeed, CCM is the nucleus of all the powers. Through elections, the party forms the government of the day. The president remains so powerful as long as he or she works for the interests of the party as per Article 15(1) of the constitution of CCM. There has no situation where a president, however popular he or she may be, can work independently of the party. Yet, as the chairperson of the party, he or she cannot decide unilaterally on party matters which require approval of other members particularly in national level meetings. Thus the president has always worked to advance the interests of the party. It is interesting to note that in Tanzania CCM outlasts the presidents since independence.

\section{References}

AJM (Association of Journalists and Media Workers). (1995). Election Media Bulletin, "Monitor", Tanzania, 3, September 14-21.

Biezen, I., \& Kopecky, P. (2007). "The State and the Parties: Public Funding, Public Regulation and Rent-Seeking in Contemporary Democracies”, Party Politics, 13(2): 235-254. http://dx.doi.org/10.1177/1354068807073875

Bratton, M., \& Masunungure, E. (2008). “Zimbabwe’s Long Agony”, Journal of Democracy, 19(4): 41-55. http://dx.doi.org/10.1353/jod.0.0024

CCM (2006). Hotuba ya Mwenyekiti wa Chama Cha Mapinduzi, Mheshimiwa Benjamini William Mkapa, Mkutano Mkuu wa CCM 2006: Hotuba ya Mwenyekiti ya Kung’atuka na Kuaga, Chimwaga, Dodoma, 25 June 2006.

Centre for democracy (1999). The role of Media in Democracy: A strategic approach, Technical Publication Series, June 1999, Center for Democracy and Governance, Bureau for Global Programs, Field Support, and Research, U.S. Agency for International Development, Washington, D.C.

Chaligha, A. et al. (2002). "Uncritical Citizens or Patient Trustees? Tanzanians' views of Political and Economic Reform” Afrobarometer Paper No. 18.

Chu, Y. (1999). “A Born-Again Dominant Party? The Transformation of the Kuomintang and Taiwan's Regime Transition”. In: Giliomee, Hermann. and Simkins, Charles (eds). The Awkward Embrace: One - Party Domination and Democracy. Cape Town: Tafelberg Publishers, 61-95.

EISA (2003). The Electoral Institute of Southern Africa Report. Retrieved from http://www.eisa.org.za/ (January 19, 2012).

Forrest, J., \& Marks, G. N. (1999). "Research Note; The Mass Media, Election Campaigning and Voter Response: The Australian Experience”, Party Politics, 5(1):99-114. http://dx.doi.org/10.1177/1354068899005001006

Franklin, J. C. (2002). "Political Party Opposition to Non-competitive Regimes: A Cross-National Analysis”, Political Research Quarterly, 55(3): 521-546.

Greene, K. F. (2007). Why Dominant Parties Lose: Mexico's Democratization in Comparative Perspective. Cambridge: Cambridge University Press. http://dx.doi.org/10.1017/CBO9780511509803

Hameso, S. (2002). "Issues and Dilemmas of Multi-Party Democracy in Africa”, West African Review, 13(2).

Huntington, S. P. (1991). The Third Wave : Democratization in the Late Twentieth Century. Norman: University of Oklahoma Press, Publishing Division of the University of U.S.A. 
Katz, R., \& Mair, P. (1995). “Changing Models of Party Organisation and Party Democracy: The Emergence of the Cartel Party”, Party Politics, 1(1): 5-28. http://dx.doi.org/10.1177/1354068895001001001

Katz, R., \& Mair, P. (2002). "The Ascendancy of the Party in Public Office: Party Organisational Change in Twentieth-Century Democracies”. In: Gunther, Richard et al. (eds). Political Parties: Old Concepts and New Challenges. Oxford: Oxford University Press, 113-135.

Kikwete, M. (2005). Speech by the President of the United Republic of Tanzania, His Excellency Jakaya Mrisho Kikwete, on Inaugurating the Fourth Phase Parliament of the United republic of Tanzania, Parliament buildings, Dodoma, 30 December 2005. Retrieved from http://www.parliament.go.tz/ (September 3, 2011).

Kikwete. M. (2008). Hotuba ya Rais wa Jamhuri ya Muungano wa Tanzania, Mheshimiwa Jakaya Mrisho Kikwete aliyoitoa Bungeni, Dodoma, Tarehe 21 Agosti 2008. Retrieved from http://www.parliament.go.tz/ (August 27, 2011).

Komarov, E. N. (1992). “The Emergence of a Multiparty System in the Soviet Union”. In: Vanhanen, Tatu (ed). Strategies of Democratization. Washington, DC: Taylor and Francis, 55-75.

Levitsky, S., \& Way, L. A. (2010). “Why Democracy Needs a Level Playing Field”, Journal of Democracy, 21 (1): 57-68. http://dx.doi.org/10.1353/jod.0.0148

Luanda, N. (1997). "The Role of the Media in the Transition to Multiparty Politics and the 1995 General Elections”. In: Mushi, Samuel S. and Mukandala, Rwekaza S. (eds). Multiparty Democracy in Transition: Tanzania's 1995 General Elections, Dar es Salaam. Tanzania Election Monitoring Committee (TEMCO), Department of Political Science and Public Administration, University of Dar es Salaam, 117-148.

Makulilo, A. B. (2008). Tanzania: A De Facto One Party State? VDM Verlag Dr. Muller Aktiengesellschaft \& Co. Kg, Germany.

Makulilo, A. B. (2009). “Independent Electoral Commission in Tanzania: A False Debate?”, Representation, 45(4):435-453. http://dx.doi.org/10.1080/00344890903257409

Mallya, E. (2006). "Religion and Elections in Tanzania Mainland”. In: Mukandala, Rwekaza S. et al. (eds). Justice, Rights and Worship: Religion and Politics in Tanzania. Dar es Salaam: E\&D Limited, 395-415.

Mbaruku, H. (2005). “Kikwete kupingwa” Alasiri 26 Mei 2005. Retrieved from http://kurayangu.com/ (August 28, 2011).

MCT (Media Council of Tanzania). (2000). Media Monitoring Report of 2000 Elections.

Meirowitz, A. (2008). “Electoral Contests, Incumbency Advantages and Campaign Finance”, Journal of Politics, 70(3): 681-699. http://dx.doi.org/10.1017/S0022381608080699

MISA (Media Institute of Southern Africa). (2005). Tanzania Election Media Monitoring Report

NEC (2001). Report of the National Electoral Commission on the 2000 Presidential and Parliamentary and Councillors’ Elections. Dar es Salaam: Dar es Salaam University Press.

NEC (2006). The Report of the National Electoral Commission on the 2005 Presidential, Parliamentary and Councilors' Elections. Dar es Salaam: Dar es Salaam University Press.

NEC (2011). The Report of the National Electoral Commission on the 2010 Presidential, Parliamentary and Councilors' Elections. Dar es Salaam.

NEC (National Election Commission). (1996). Report of the National Electoral Commission on the 1995 Presidential and Parliamentary Elections. Dar es Salaam: United Republic of Tanzania, Government Printer.

Ngware, S. (1997). “Civil Society and Forms of Political Participation in Tanzania”. In: Hofmeister, Wilhelm. and Ingo, Scholz, (eds). Traditional and Contemporary Forms of Local Participation and Self-Government in Africa. International Conference-Nairobi, Kenya, 9-12 October 1996. Johannesburg: Konrad Adenauer Stiftung.

Ong’wamuhana, K. (1978). "Human Rights in Tanzania: A Constitutional Overview,” Eastern Africa Law Review: A Journal of Law and Development, 11-14: 240-325.

REDET (Mpango wa Utafiti na Elimu ya Demokrasia). (2007). Maoni ya Wananchi Kuhusu Utendaji wa Vyama vya Siasa Tanzania, Idara ya Sayansi ya Siasa na Utawala, Chuo Kikuu Cha Dar es Salaam.

Ruotsalainen, P. J. (2009). Under the Same Shade: Popular Perceptions of Political Change and the Challenges of Consolidating Multiparty Democracy in Tanzania. PhD Dissertation, University of Gothenburg. 
Samuels, D. (2001). "Incumbents and Challengers on a Level Playing Field: Assessing the Impact of Campaign Finance in Brazil”, The Journal of Politics, 63(2): 569-584. http://dx.doi.org/10.1111/0022-3816.00079

Satu, R. (2007). Empowering the poor?: Civic Education and Local level participation in rural Tanzania and Zambia. A Dissertation Submitted in Partial Fulfilment of the Requirements for the Degree of Doctor of Philosophy in the College of Arts and Sciences Georgia State University.

Schedler, A. (2010). “Authoritarianism's Last line of Defense”, Journal of Democracy, 21(1): 69-80. http://dx.doi.org/10.1353/jod.0.0137

Shivji, I. G. (1991). “Towards a New Democratic Politics” University of Dar es Salaam Academic Staff Assembly (UDASA) Bulletin, No. 12.

Shivji, I. G. (1993). “The Changing State: From an Extra-Legal to an Intra-Legal State in Tanzania” in Fimbo, Mgongo and Mvungi, Sengondo (eds) Constitutional Reforms for Democratisation in Tanzania, Faculty of Law, University of Dar es Salaam.

Shivji, I. G. (2006). Let the People Speak: Tanzania Down the Road to Neo-Liberalism. Dakar: Council for the Development of Economic and Social Research in Africa (CODESRIA).

Synovate: Tanzania media election coverage September 2010, Dar es Salaam

TEMCO (2001). Tanzania Election Monitoring Committee). 2001. The Report of the 2000 General Elections in Tanzania. Dar es Salaam: University of Dar es Salaam.

TEMCO (2006). The Report of the 2005 General Elections in Tanzania. Dar es Salaam: University of Dar es Salaam.

TEMCO (Tanzania Election Monitoring Committee). (1997). The Report of the 1995 General Elections in Tanzania. Dar es Salaam: University of Dar es Salaam.

URT (1999). Kamati ya Kuratibu Maoni Kuhusu Katiba, Kitabu cha Kwanza: Maoni ya Wananchi na Ushauri wa Kamati, Dar es Salaam.

URT (2005). Code of Ethics and Conduct for Public Service. Dar es Salaam: Government Printer, Dar es Salaam.

URT (United Republic of Tanzania) (1991). The Presidential Commission on Single Party or Multiparty System in Tanzania: Report and Recommendations of the Commission on the Democratic System in Tanzania, (Volume I), Dar es Salaam University Press.

Wallerstein, I. (1966). “The Decline of the Party in Single-Party African States”. In: LaPalombara, Joseph. and Weiner, Myron (eds). Political Parties and Political Development. Princeton, NJ: Princeton University Press, 201-214.

Widner, J. A. (1992). The Rise of a Party-State in Kenya: From "Harambee!" to "Nyayo!". Berkeley: University of California.

\section{Notes}

Note 1. Interview with Mr. John Mrema (Director of Parliamentary and Council Affairs) CHADEMA, 13 February 2009. Interview with Mr. Benedicto Mutungirehi (National Publicity Secretary) TLP, 18 March 2009. Interview with Mr. Hussein Mmasi (Policy Development Officer and Trainer) CUF, 21 February 2009.

Note 2. Dr. Slaa was a Member of Parliament from Karatu through the opposition party ticket CHADEMA. He has been very critical to the government and the ruling party CCM. Although the statement by the President appeared as a joke, in reality he was sending him a message. But the statement also revealed how the president may misuse his or wider discretional powers either for his or her own benefits or rather for the benefits of his or her party. This is normally done rather strategically than openly. See Speech by the President of the United Republic of Tanzania, His Excellency Jakaya Mrisho Kikwete, to Members of Parliaments on 21 August, 2008 in Dodoma http://www.parliament.go.tz/, (accessed: 27 August, 2011).

Note 3. See Jamhuri ya Muungano wa Tanzania, Bunge la Tanzania, Majadiliano ya Bunge, Taarifa Rasmi (Hansard) Mkutano wa Kumi, Kikao Cha Kumi-Tarehe 14 Februari 2008. Kimetayarishwa na Kupigwa Chapa na Idara ya Taarifa Rasmi za Bunge, Ofisi ya Bunge, Dodoma. In February 2008 when the Parliament of Tanzania was discussing the report on "Richmond Scandal" on power supply and the associated corruption, the answer as to why these government officials are not confident to orders from their bosses within the party-state 
fused structure was given. In that incidence it was observed that the report by the anti-corruption bureau (PCCB) which initially undertook the investigation of the "Richmond Scandal" revealed that no corruption of any sort was discovered. However, once the special committee of the parliament undertook the second investigation, a lot of corruption behaviour was revealed. It was thus to be explained why such disparity in terms of findings was the case. 